\title{
Clinical Biochemistry Reports- Effective Tools for Early clinical Exposure in Improving the Interpretation Skills of First MBBS Students
}

\author{
K. Suganthy ${ }^{1}$, M. Jeyakumar², P. K. Mohanty³, B. Sumanth Kumar, A. Kavitha ${ }^{5}$ \\ ${ }^{1}$ Professor, Department of Biochemistry, Velammal Medical College Hospital and Research Institute, Madurai, \\ Tamilnadu, India. ${ }^{2}$ Asssistant Professor, Department of Biochemistry, Velammal Medical College Hospital and \\ Research Institute, Madurai, Tamilnadu, India. ${ }^{3}$ Professor and HOD, Department of Biochemistry, Velammal Medical \\ College Hospital and Research Institute, Madurai, Tamilnadu, India. ${ }^{4}$ Assistant Professor, Department of Biochemistry, \\ Meenakshi Medical College and Research Institute, Kanchipuram, Tamilnadu, India. ${ }^{5}$ Tutor, Department of \\ Biochemistry, Velammal Medical College Hospital and Research Institute, Madurai, Tamilnadu, India.
}

\section{ABSTRACT}

\section{BACKGROUND}

Learning clinical biochemistry has a lot of importance in understanding the clinical subjects which are taught later. Enhancing the interpretation skills of biochemical lab reports helps students in learning the clinical diagnosis, treatment and prognosis of a disease. It also provides platform for early clinical exposure and motivates student centered learning.

\section{METHODS}

Pre and post learning outcomes on interpretation skills of Liver Function Test (LFT) were undertaken. Totally 134/147 students participated \& were assessed for interpretation skills with 9 LFT reports. Small group teaching comprised of one faculty for 30 students. LFT was taken as didactic lecture and case-history-based learning; interpretation of LFT reports was discussed. After 2 weeks, clinical biochemistry reports and Biochemistry Test Request Forms (TRF) of OP and IP with brief clinical history were provided to the students. Pre and post-test scoring was done, and students' feedback perception was also obtained.

\section{RESULTS}

The residual knowledge for interpretation of LFT after didactic lecture and casehistory-based learning was incorrectly done by $>50 \%$ of the students. Interpretation skill was lowest for Newborn LFT (18/134). Clinical biochemistry reports were effective in enhancing student's interpretation skills with $\mathrm{p}$ value $<0.05$. Student's interpretation skills of normal/abnormal LFT improved from 28 to $72 \%$. Students agreed that this session motivated them for further learning and selfassessment.

\section{CONCLUSIONS}

Multiple ways of teaching and learning assessment methods should be adopted to understand the clinical relevance of laboratory investigations for improving the interpretation skills among undergraduate medical students.

\section{KEY WORDS}

Liver Function Test, Interpretation Skill, Early Clinical Exposure
Corresponding Author:

Dr. M. Jeyakumar,

Department of Biochemistry,

Velammal Medical College Hospital and Research Institute, Madurai Tuticorin Ring Road, Anuppanadi, Madurai, Tamilnadu, India.

E-mail: drjaidyogi@gmail.com

DOI: $10.14260 / \mathrm{jemds} / 2019 / 656$

Financial or Other Competing Interests: None.

How to Cite This Article:

Suganthy K, Jeyakumar M, Mohanty PK, et al. Clinical biochemistry reports- effective tools for early clinical exposure in improving the interpretation skills of first MBBS students. J. Evolution Med. Dent. Sci. 2019;8(40):3019-3023, $10.14260 /$ jemds/2019/656

Submission 22-07-2019, Peer Review 18-09-2019, Acceptance 25-09-2019, Published 07-10-2019. 


\section{BACKGROUND}

Biochemistry is a key subject of medical curriculum which forms the base of laboratory medicine and includes diagnostic methodology. Clinical biochemistry topics link the basic knowledge with clinical content. Hence, these topics are extremely important in learning process and for practice of medicine in future. ${ }^{1}$ Health professionals need to develop analytic and diagnostic thinking skills and not just a mere accumulation of large amount of facts. ${ }^{2}$

The Re-structuring of practical Biochemistry curriculum has been already suggested to have more clinical relevance. Medical Council of India (MCI) recommends good teaching learning practice by ECE. Also, Medical education is being reviewed at various levels for training in the laboratory medicine. ${ }^{3,4}$ The role of laboratory testing in the care of patients is uniformly recognized as a critical component of modern medical care. Indeed, the Centers for Disease Control and Prevention (CDC) published a monograph in May 2008, entitled "Laboratory Medicine: A National Status Report" that noted: "An integral component of care is laboratory medicine, which extends across research, clinical (i.e., screening, diagnosis and treatment), and public health settings. ${ }^{5}$

Enhancing the interpretation skills of lab investigation report during pre \& para clinical curriculum is of great significance for appropriate health care delivery. Learning to interpret Biochemistry laboratory reports not only develops mental skills and the acquisition of knowledge (Knowledge category of cognitive domain) but also enhances the ability to utilize the knowledge in a new situation (Analysis category of cognitive domain).

Attainment of higher cognitive learning process, deep approach of learning and critical thinking is supported in various studies. ${ }^{6,7}$ The best instructional format for teaching medical students stimulating their critical thinking in interpretation lab reports is not clear. This study is an attempt to identify a potentiality for using clinical Biochemistry reports as an effective tool for early clinical exposure and in improving the interpretation skills of first MBBS students. ${ }^{8,9}$ So that students can get actively involved in the process of learning instead of memorizing the few exam charts used for case based discussion. This prepares them for a lifelong self-directed learning process.

We wanted to evaluate the interpretation skills, learning outcome, perception of students towards adoption of the new teaching technique (didactic lecture and case-based learning) by using clinical biochemistry reports and LFT results among the first MBBS students.

\section{METHODS}

This is a descriptive study conducted in the Department of Biochemistry, among the 147 undergraduate medical students admitted during the period of 2016-17 in VMCHRI, Tamilnadu, India. There were only 134 students enrolled completed the module. So those students completed and given post feedback session are presented as study subjects. Preliminary planning and preparation work involved discussion and forming a core group of biochemistry faculties. This is a descriptive study design of teaching module comprising multiple teaching tools like didactic lecture, case-based learning and usage of clinical Biochemistry reports.

Enhancing interpretation skill of Liver function test was decided for the learning process. 6 patients from Medicine ward arranged to show clinically with their laboratory investigations. Biochemistry Test Request forms and the respective clinical Biochemistry reports were collected from hospital laboratory. Each set included 9 normal and abnormal LFT reports from Master health check-up, Chronic liver disease, Acute Hepatitis, Cirrhosis, chronic kidney disease, Alcoholics, oncology, Paediatric, Newborn, Psychiatric and respiratory medicine patients. Totally 30 sets made of different values of LFT reports collected, 15 sets were used for small group teaching and 15 sets used for assessment of interpretation analysis. The 147 students were divided into 5 small groups comprising 30 students for 1 faculty.

Implementation involved the following steps-

a. Didactic Lecture on LFT.

b. First Week- Case history based learning and clinical cases from the Medicine ward was used for teaching in small groups. (Appendix A - example of acute viral hepatitis). A Pre and Post-test questionnaire was assessed on the residual knowledge of interpretation skills on LFT investigation. (Appendix B).

c. Second Week - Student interpretation skills was assessed by clinical biochemistry laboratory reports along with the TRF form. Interactive small group sessions on routine LFT investigations requested from various disciplines of Hospital were discussed again. Clarifications and explanations were given regarding Biochemical basis of disorder and presenting clinical features, abnormal lab tests in support of diagnosis, complications and treatment in short wherever required. Each student has to interpret the 9 LFT reports at the end of learning session. Self-Scoring was done under the faculty guidance. (Appendix C)

d. Post session student perception feedback was taken from the participated students at the end of 2 nd week session. This questionnaire was validated by the members of MEU of institute. (Appendix D).

\section{Statistical Analysis}

Data from excel sheet was used for generating graphs. Data was exported to Graph pad statistical analysis software. All the numerical variables were expressed as mean \pm S.D. Score of correct answers for each respondent was computed by summing up the correct answers to obtain a score from 0-9 for each participant. Paired student's ' $t$ ' test for the comparison between the pre and post test scores. The statistical significance was defined as a p value of $<0.05$.

To evaluate the participant's/student's qualitative feedback on acceptability and usefulness of this method, questionnaire with Likert scale was undertaken. The response obtained was in terms of strongly agree, agree, neutral, disagree and strongly disagree. The data obtained were presented as percentage. 


\section{RESULTS}

This study comprises the data of $134 / 147$ students completed the Liver function test learning process. The Table- 1 shows the residual knowledge after the didactic lecture and case history-based discussion of question 2 and 3 as shown in Appendix B namely Enumerate biochemical parameters of LFT and their reference ranges. The Figure 1 shows the residual knowledge of Interpretation of LFT of the question $4,9 \& 10$. Students were not able to interpret newborn Bilirubin value and only 18/134 students interpreted correctly. All other questions of Appendix B were answered $>80 \%$ correctly by the students.

\begin{tabular}{|c|c|c|}
\hline 134 Students & $\begin{array}{c}\text { Enumerate the Biochemical } \\
\text { Tests of LFT }\end{array}$ & $\begin{array}{c}\text { Reference Range of } \\
\text { the LFT }\end{array}$ \\
\hline Correctly N (\%) & $64(48 \%)$ & $49(37 \%)$ \\
\hline Incorrectly N (\%) & $70(52 \%)$ & $85(63 \%)$ \\
\hline \multicolumn{2}{|c|}{ Table 1. Pre-Test for Residual Knowledge on LFT after Didactic Lecture } \\
\hline
\end{tabular}

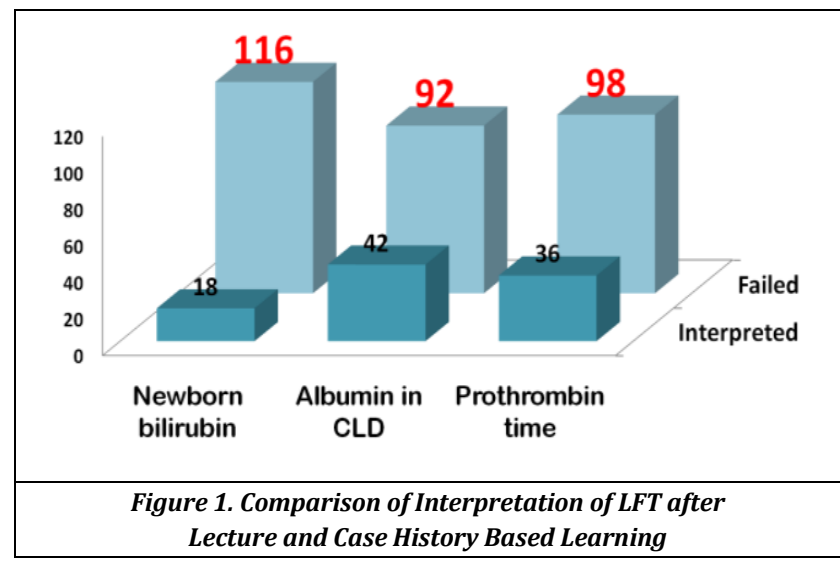

In the second week, student's interpretation skills were assessed by clinical biochemistry laboratory reports along with the TRF form with Interactive sessions on routine LFT investigations requested from various disciplines of Hospital. Scoring was done for each student for correct interpretation of 9 LFT reports and is represents as bar diagram in Figure 2.

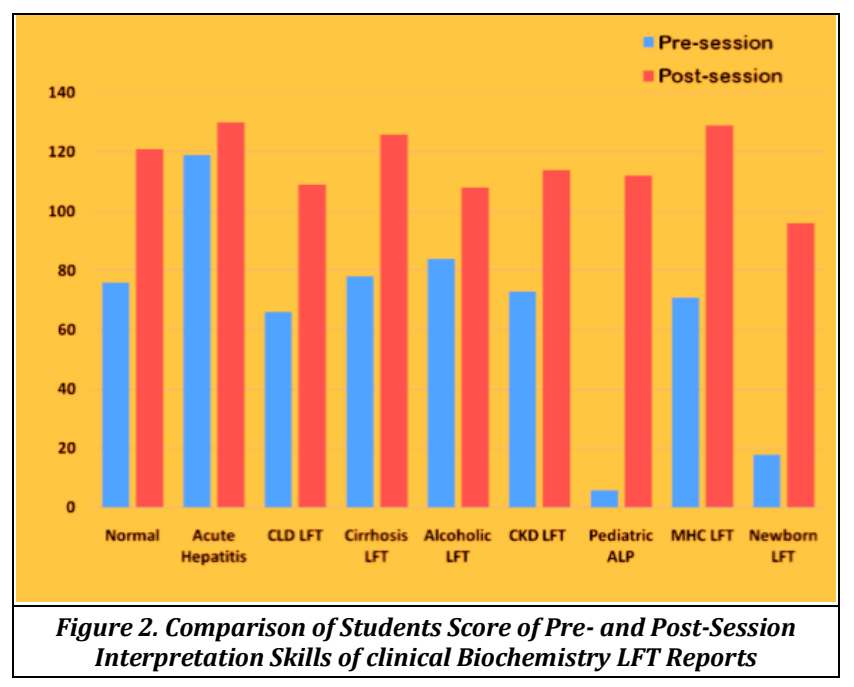

Clinical biochemistry reports were effective in enhancing student's interpretation skills, showed mean \pm SD post test score of $116.1 \pm 11.37(\mathrm{p}$ value $<0.05)$ and statistically significant as shown in table 2 .

\begin{tabular}{|c|c|c|c|}
\hline $\begin{array}{c}\text { Interpretation } \\
\text { Skill - LFT Report }\end{array}$ & $\begin{array}{c}\text { Pre-Test Score } \\
\text { Mean } \pm \text { SD }\end{array}$ & $\begin{array}{c}\text { Post-Session Test } \\
\text { Score Mean } \pm \text { SD }\end{array}$ & p-Value \\
\hline & $65.7 \pm 34.19$ & $116.1 \pm 11.37$ & $\mathbf{0 . 0 0 0 1}$ \\
\hline \multicolumn{3}{|c|}{ Table 2. Overall Effect of Interpretation Skills of clinical } \\
Biochemistry Reports in Learning and Assessment \\
\hline $\begin{array}{c}\text { A majority of }>72 \% \text { students rated "Strongly agreed" and "Agree" on a 5-point } \\
\text { Likert scale shown as percentage in Table-3 }\end{array}$
\end{tabular}

\begin{tabular}{|c|c|c|c|c|c|c|}
\hline \multirow[t]{2}{*}{ No. } & \multirow[t]{2}{*}{$\begin{array}{c}\text { Student Perception } \\
\text { Comments }\end{array}$} & \multicolumn{5}{|c|}{$\begin{array}{c}\text { Response in No. of Students of } \\
\text { Total } 134\end{array}$} \\
\hline & & 1 & 2 & 3 & 4 & 5 \\
\hline 1 & $\begin{array}{l}\text { Atmosphere of the session was } \\
\text { comfortable and relaxed }\end{array}$ & 38 & 58 & 27 & 9 & 2 \\
\hline 2 & $\begin{array}{l}\text { Helpful in recalling the } \\
\text { knowledge of LFT }\end{array}$ & 25 & 73 & 30 & 3 & 3 \\
\hline 3 & $\begin{array}{l}\text { Allowed to ask questions whenever } \\
\text { required }\end{array}$ & 24 & 52 & 51 & 6 & 1 \\
\hline 4 & $\begin{array}{c}\text { Provided an opportunity to } \\
\text { clarify concepts }\end{array}$ & 65 & 48 & 14 & 4 & 3 \\
\hline 5 & $\begin{array}{c}\text { Stimulated to take part in further } \\
\text { self-directed learning }\end{array}$ & 35 & 64 & 30 & 2 & 2 \\
\hline 6 & $\begin{array}{l}\text { Improved confidence of } \\
\text { Interpretation skill of LFT }\end{array}$ & 26 & 70 & 30 & 6 & 2 \\
\hline 7 & $\begin{array}{l}\text { Recommend for } \\
\text { 1st MBBS students }\end{array}$ & 51 & 47 & 24 & 6 & 6 \\
\hline 8 & $\begin{array}{l}\text { Recommend similar session for } \\
\text { practical/clinical teaching hours }\end{array}$ & 47 & 55 & 25 & 3 & 4 \\
\hline 9 & $\begin{array}{c}\text { Session helpful in your own } \\
\text { self-assessment }\end{array}$ & 29 & 65 & 30 & 7 & 3 \\
\hline \multirow[t]{2}{*}{10} & $\begin{array}{c}\text { Session helpful in understanding } \\
\text { and interpretation of LFT }\end{array}$ & 34 & 70 & 22 & 6 & 2 \\
\hline & Mean N (\%) & $37.4(28)$ & $60.2(45)$ & $28.3(21)$ & $5.2(4)$ & $2.8(2)$ \\
\hline \multicolumn{7}{|c|}{$\begin{array}{l}\text { Table 3. Students Feedback of the Session: } \\
\text { Results of Perception Based Questionnaire }\end{array}$} \\
\hline & ngly agree, 2 - Agree, 3 - Neutral & & 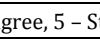 & & & \\
\hline
\end{tabular}

\section{DISCUSSION}

Students of Biochemistry should develop analytic, interpretation and diagnostic thinking skills and not just a mere accumulation of large amount of facts. The pre \& posttest on residual knowledge after the didactic lecture on LFT is not enough to develop the interpretation skills. ${ }^{10,4}$ As $>70 \%$ students failed to interpret abnormal reports of newborn, chronic liver diseases which is the accepted fact of didactic lectures in teaching clinical biochemistry. The challenge of imparting a large amount of knowledge within a limited period in a way it is clearly understood and retained by a student is a formidable one.2,11

In the present study, as we wanted the knowledge of scientific approach to Laboratory diagnosis and interpretation skills should be made rooted in preclinical undergraduate medical education. Case history-based learning and ECE of clinical cases was undertaken in the next practical session as it is more effective than lecture method. Then student's interpretation skills were assessed by clinical biochemistry laboratory reports along with the TRF form. Comparison of pre-post-test scoring observed that there was improvement for interpretation of LFT. The interpretation of LFT was $>50 \%$ for both normal and abnormal Lab reports but for Newborn (18/134), 42/134 in Chronic liver diseases and Prothrombin time (18/134) was correctly interpreted by students. The advantages of CBL are that it promotes selfdirected learning, improves decision making and problemsolving attitude. The students have to think, define, struggle with problem and try to resolve it. This process enhances student's ability to synthesize, evaluate and apply information and concepts.2,12 This study suggests that CBL and ECE has definitely a positive effect in learning, further the 
interpretation skill teaching using TRF form and clinical Biochemistry reports of OP/IP enhanced their skills. The post session scoring showed interpretation skill improved to 116/134 (87\%). Clinical biochemistry reports were effective in enhancing student's interpretation skills with $p$ value $<0.05$. Therefore, multiple modalities lead to improvement in learning experience are supported by $72 \%$ students in their feedback form to introduce in First MBBS like in a study of Heidiet al. ${ }^{13}$

These sessions were helpful for students in selfassessment of their interpretation skills and apply the theory knowledge into clinical context was supported by $>75 \%$ students. Students can make abstract concepts concrete and correlate with the clinical features similar to other studies.5,14

Limitation of this study is that the session was conducted for only one topic LFT, as much of preplanning required. All the entities of clinical biochemistry reports of a case cannot be discussed at this level. Collecting appropriate TRF \& stating specific learning objectives are challenging and crucial at first year stage similar to learning process done for CBL in various other studies. ${ }^{15}$ Advantage in using the clinical biochemistry reports is that it becomes both learning and assessment tool added to regular teaching of clinical biochemistry. This view is supported by a series of interactive case studies in clinical chemistry has been developed to promote diagnostic reasoning 16 by Hooper et al. Information about laboratory tests is now available on handheld computers, and one such program received a positive reception from students in an internal medicine clerkship. ${ }^{17}$

Medical education on laboratory testing is inadequate. Students memorize the diagnosis and interpretation of few case based scenarios practiced for final pass in examination. Despite the integral role of laboratory testing in the practice of medicine, formal teaching of laboratory medicine is a relatively neglected component of the medical school curriculum. Without sufficient knowledge of laboratory tests, health care providers are more prone to inappropriate ordering and mistakes in interpreting test results and adverse outcomes. ${ }^{5}$

Further development of this teaching module to teach skills in common laboratory procedures with the use of the hospital information system to provide guidelines on laboratory ordering and interpretation, as well as the costs of testing, is another means of providing immediate and lifelong learning opportunities in medicine.

\section{CONCLUSIONS}

Multiple modalities of T-L assessment methods should be adopted to improve the interpretation skills. Recently, series of strategies and alternatives are developing for teaching biochemistry. There is a continued need of teachers to develop the expanded learning styles of future students to make it more interesting and also to stimulate further learning and self-assessment by students. Also, laboratory reports can be used as formative assessment tool. This study recommends the use of clinical biochemistry reports for practical sessions in pre-clinical, para clinical, interns and lab side teaching for MBBS students. An in-depth knowledge of laboratory medicine principles is vital to all practicing physicians. We hope this report helps to design curriculum content for primary care comprising evidence-based laboratory medicine educational outcomes.

\section{Appendix A}

A 40-year-old women presents with fever, jaundice, body pain and arthralgia. Her Liver function test result showed the following findings-

1. Total Bilirubin: $3.8 \mathrm{mg} / \mathrm{dl}$

2. Direct Bilirubin: $2.1 \mathrm{mg} / \mathrm{dl}$

3. Indirect Bilirubin: $1.7 \mathrm{mg} / \mathrm{dl}$

4. AST: $750 \mathrm{IU} / \mathrm{l}$

5. ALT: $650 \mathrm{IU} / \mathrm{l}$

6. ALP: $250 \mathrm{IU} / \mathrm{l}$

7. Total Protein: $6.8 \mathrm{~g} / \mathrm{dl}$

8. Albumin: $3.8 \mathrm{~g} / \mathrm{dl}$

9. Urine Bile salts: +

10. Urine Bile pigments: ++

\section{Appendix B}

Pre \& Post-test on interpretation of LFT with Didactic lecture $\& \mathrm{CBL}$

1. Give at least 5 indications for the request of LFT in patients.

2. Name all the biochemical parameters analysed in LFT.

3. Name the enzymes investigated in LFT and their reference range.

4. Interpretation of the newborn Bilirubin result.

5. Which enzyme is specific for Obstructive jaundice?

6. Which enzymes are requested in alcoholism?

7. What are the other investigations done for Acute Hepatitis?

8. Why LFT requested before starting/during an Anti TB regimen?

9. What is the interpretation of Serum albumin level in acute and chronic liver diseases? Why so?

10. Normal Prothrombin time?

\section{Appendix C}

Pre \& Post-test interpretation of LFT with clinical Biochemistry reports. Students will first mark the sheet based on the interpretation skills, then self-scoring under the guidance of faculty. Mark: N-Normal, + for Increased, - for Decreased, $\mathrm{X}$ for no interpretation.

\begin{tabular}{|l|l|l|l|l|l|l|l|l|l|l|l|l|l|l|l|l|l|l|}
\hline $\begin{array}{l}\text { LFT } \\
\text { PARAMETERS }\end{array}$ & 1 & 1 & 2 & 2 & 3 & 3 & 4 & 4 & 5 & 5 & 6 & 6 & 7 & 7 & 8 & 8 & 9 & 9 \\
\hline Total Bilirubin & & & & & & & & & & & & & & & & & & \\
\hline Direct Bilirubin & & & & & & & & & & & & & & & & & & \\
\hline Indirect Bilirubin & & & & & & & & & & & & & & & & & & \\
\hline AST & & & & & & & & & & & & & & & & & & \\
\hline ALT & & & & & & & & & & & & & & & & \\
\hline ALP & & & & & & & & & & & & & & & & \\
\hline GGT & & & & & & & & & & & & & & & \\
\hline Urine Bilirubin & & & & & & & & & & & & & & & & & \\
\hline Urine Bile salt & & & & & & & & & & & & & & \\
\hline Other parameters & & & & & & & & & & & & & & & \\
\hline Clinical diagnosis & & & & & & & & & & & & & & & \\
\hline
\end{tabular}

\section{Appendix D}

Student's Perception - Post Session Feedback.

1. Atmosphere of the session was comfortable and relaxed. 
2. Session helpful in recalling the knowledge of LFT.

3. Allowed you to ask questions whenever required.

4. Recommend this session's usefulness to first MBBS students.

5. Recommend similar sessions for interpretation of other lab investigations in practical/clinical teaching hours.

6. Provided an opportunity to clarify the concepts.

7. Session helpful in your own self-assessment.

8. Stimulates you for further self-directed learning.

9. Session helpful in understanding and interpretation of LFT.

10. Improvement of Confidence of interpretation of LFT.

\section{REFERENCES}

[1] Amandeep K, Sahiba K, Tejinder S, et al. Early clinical exposure to enhance the learning of biochemistry in first year M.B.B.S students. International Journal of clinical Biochemistry and Research 2018;5(3):401-5.

[2] Nair SP, Shah T, Seth S, et al. Case based learning: a method for better understanding of biochemistry in medical students. Journal of clinical and Diagnostic Research 2013;7(8):1576-8.

[3] Dandeker SP, Maksane SN, McKinley D. A survey validation and analysis of undergraduate medical biochemistry practical curriculum in Maharashtra, India. Ind J Clin Biochem 2012;27(1):52-60.

[4] Sood R. Medical education in India. Med Teach 2008;30(6):585-91.

[5] Smith BR, Aguero-Rosenfeld M, Anastasi J, et al. Educating medical students in laboratory medicine. A proposed curriculum. Am J Clin Pathol 2010;133(4):53342.

[6] Darabi A, Hemphill J, Nelson DW, et al. Mental model progression in learning the electron transport chain: effects of instructional strategies and cognitive flexibility. Adv Health Sci Educ Theory Pract 2010;15(4):479-89.
[7] Kulak V, Newton G. A guide to using case-based learning in biochemistry education. Biochemistry and Molecular Biology Education 2014;42(6):457-73.

[8] McRae MP. Using clinical case studies to teach biochemistry in a doctoral program: a descriptive paper. Creative Education 2012;3(7):1173-6.

[9] Popil I. Promotion of critical thinking by using case studies as teaching method. Nurse Education Today 2011;31(2):204-7.

[10] Ananthakrishnan N. Acute shortage of teachers in medical colleges: existing problems and possible solutions. Natl Med J India 2007;20(1):25-9.

[11] Murugaiyan S, Ramasamy R, Srinivasan AR, et al. Selfdirected learning module in biochemistry: a teaching learning study conducted on graduate south Indian medical students. International Journal of Health Sciences \& Research 2016;6(5):125-32.

[12] Joshi KB, Nilawar AN, Thorat AP. Effect of case based learning in understanding clinical biochemistry. Int J Biomed and Adv Res 2014;5(10):516-8.

[13] Lujan HL, DiCarlo SE. First year medical students prefer multiple learning styles. Adv Physiol Educ 2006;30(1):13-6.

[14] Imamwerdi BW. The effects of early clinical exposure on medical laboratory technology students: its effect on internship period and their professional carrier. Webmed Central Medical Education 2013;4(1):WMC003926.

[15] Suhasini P, Joshi KP, Swaroopachary RS, et al. An effective approach in learning clinical biochemistry case based learning. Journal of Education Technology in Health Sciences 2017;4(2):62-4.

[16] Hooper J, O'Connor J, Cheesmar R, et al. Tutorial software for clinical chemistry incorporating interactive multimedia clinical cases. Clin Chem 1995;41(9):1345-8.

[17] Schreiber WE, Busser JR, Huebsch S. A portable laboratory test reference for handheld computers: evaluation on an internal medicine clerkship. Am J Clin Pathol 2008;129(3):439-44. 